\title{
Effect of different compounds on the induction of laccase production by Agaricus blazei
}

\author{
J.S. Valle ${ }^{1}$, L.P.S. Vandenberghe ${ }^{2}$, A.C.C. Oliveira', M.F. Tavares ${ }^{1}$, G.A. Linde ${ }^{1}$, \\ N.B. Colauto ${ }^{1}$ and C.R. Soccol ${ }^{2}$ \\ ${ }^{1}$ Programa de Pós-Graduação em Biotecnologia Aplicada à Agricultura, \\ Laboratório de Biologia Molecular, Universidade Paranaense, \\ Umuarama, PR, Brasil \\ 2Laboratório de Processos Biotecnológicos, Departamento de Engenharia Química, \\ Universidade Federal do Paraná, Curitiba, PR, Brasil \\ Corresponding author: J.S. Valle \\ E-mail: jsvalle@unipar.br \\ Genet. Mol. Res. X (X): XXX-XXX (2015) \\ Received August 7, 2015 \\ Accepted August 20, 2015 \\ Published December 1, 2015 \\ DOI http://dx.doi.org/10.4238/2015.December.1.40
}

ABSTRACT. Laccases are polyphenol oxidases produced by many fungi and have many applications in textile, food and beverage, and pulp and paper industries. Laccase production can be induced using aromatic or phenolic compounds that mostly affect the transcription of laccase-encoding genes. In this study, we analyzed laccase and biomass production by Agaricus blazei in the presence of different concentrations of nitrogen, copper, and inducers such as pyrogallol, veratryl alcohol, xylidine, vanillin, guaiacol, and ethanol. Laccase production by $A$. blazei U2-4 reached $43.8 \mathrm{U} / \mathrm{mL}$ in the presence of $2.8 \mathrm{~g} / \mathrm{L}$ nitrogen and $150 \mu \mathrm{M}$ copper. However, addition of copper to the cultivation medium decreased biomass production. Different compounds differentially induced laccase production by $A$. blazei. Moreover, different concentrations of these inducers exerted different effects on laccase activity. Ethanol (1.0 mM), guaiacol $(0.5 \mathrm{mM})$, and vanillin $(0.5 \mathrm{mM})$ were the best inducers and increased laccase activity by $120 \%$ (A. blazei U2-2), 30\% (A. blazei U2-3), and $9 \%$ (A. blazei U2-4), 
respectively. In contrast, pyrogallol and xylidine decreased laccase activity but increased biomass production.

Key words: Aromatic compounds; Copper; Laccase; Nitrogen; Agaricus blazei

\section{INTRODUCTION}

In the nature, basidiomycete fungi mainly degrade lignin by producing one or more extracellular enzymes, including peroxidases and laccases (EC 1.10.3.2).

Laccases are copper-containing polyphenol oxidases that use the redox capacity of copper ions to oxidize various phenolic substrates (typically $p$-diphenol) and reduce molecular oxygen to water (Baldrian, 2006). Wide substrate specificity of laccases allows them to oxidize a broad range of compounds because of which they are extensively used in various industries such as textile, food and beverage, pulp and paper, pharmaceutical, chemical, cosmetic, nanobiotechnology, and bioremediation industries (Piscitelli et al., 2010). Biotechnological applications require large amounts of enzyme at a low cost to maintain the feasibility of the industrial processes. Therefore, continuous research should be performed to identify organisms that produce new enzymes with special properties and to optimize culture conditions for obtaining enzymes with the highest activity by using inducers and mediators (Elisashvili and Kachlishvili, 2009).

Agaricus blazei ss. Heinemann, referred to as A. brasiliensis by Wasser (Eira et al., 2002) and $A$. subrufescens Peck by Kerrigan (Kerrigan, 2005), is an edible mushroom native to Brazil and is cultivated worldwide. This fungus has received considerable attention because it exerts different biological effects such as anticancer (Bertéli et al., 2014), immunomodulatory, antidiabetic, antiinfectious, antimetastatic, anti-inflammatory, antioxidant, photoprotective, and antimutagenic effects (Costa et al., 2015).

A. blazei naturally grows in the litter layer of soil and humus layer of forests and grasslands (Eira et al., 2002). It degrades lignin and structurally similar compounds at a lower rate than white-rot fungi. A. blazei is a laccase producer (Ullrich et al., 2005; D’Agostini et al., 2011; Valle et al., 2014); however, no information is available on compounds that induce laccase production by $A$. blazei.

The present study evaluated the laccase-producing capacity of Brazilian A. blazei strains and analyzed the potential of different compounds for inducing laccase production by these strains.

\section{MATERIAL AND METHODS}

\section{Microorganisms and culture conditions}

A. blazei strain U2-4 available at the culture collection of Molecular Biology Laboratory, Paranaense University (UNIPAR), Brazil, was evaluated. Mycelia of A. blazei U2-4 were cultured on $1 \%(\mathrm{w} / \mathrm{v})$ malt extract agar (MEA) at $25^{\circ} \mathrm{C}$ and were then subcultured on $2 \%(\mathrm{w} / \mathrm{v}) \mathrm{MEA}$ at $28^{\circ} \mathrm{C}$ for 7 days to be used as inoculum. Additionally, mycelia were harvested from the surface of MEA and maintained at $-80^{\circ} \mathrm{C}$ until DNA extraction.

A. blazei U2-4 was cultivated in Erlenmeyer flasks $(250 \mathrm{~mL})$ containing $60 \mathrm{~mL}$ liquid medium consisting of $1.5 \mathrm{~g} / \mathrm{L} \mathrm{KH}_{2} \mathrm{PO}_{4}, 0.5 \mathrm{~g} / \mathrm{L} \mathrm{MgSO}, 0.5 \mathrm{~g} / \mathrm{L} \mathrm{KCl}, 0.036 \mathrm{~g} / \mathrm{L} \mathrm{FeSO} \cdot 7 \mathrm{H}_{2} \mathrm{O}$, $0.035 \mathrm{~g} / \mathrm{L} \mathrm{ZnSO} \cdot \mathrm{H}_{2} \mathrm{O}$, and $10 \mathrm{~g} / \mathrm{L}$ glucose. After sterilization at $121^{\circ} \mathrm{C}$ for $20 \mathrm{~min}, 300 \mathrm{~g} / \mathrm{L}$ sterile 
urea was added to the liquid medium to obtain a final nitrogen concentration of 0.28 or $2.8 \mathrm{~g} / \mathrm{L}$. Flasks containing the liquid medium were inoculated with the mycelia of $A$. blazei U2-4 and were maintained in the dark at $28^{\circ} \mathrm{C}$ for 21 days. After 4 days of mycelial growth, $30 \mathrm{mM} \mathrm{CuSO}_{4}$ was added to the cultivation medium to obtain a final copper concentration of $0,50,100,150,200,250$, or $300 \mu \mathrm{M}$. Laccase activity was measured on the final day of cultivation. Fungal biomass was measured gravimetrically after recovering mycelia by centrifugation ( $2900 \mathrm{~g}$ for $15 \mathrm{~min}$ at $4^{\circ} \mathrm{C}$ ) and by drying at $65^{\circ} \mathrm{C}$ until a constant mass was obtained.

Urea and $\mathrm{CuSO}_{4}$ concentrations that provided the most favorable results were used in subsequent experiments to evaluate the effect of different inducers on the laccase activity of $A$. blazei U2-4, A. blazeiU2-1, A. blazeiU2-2, and A. blazeiU2-3. Effect of pyrogallol (1,2,3-trihydroxybenzene), veratryl alcohol (3,4-dimethoxybenzyl alcohol), xylidine (2,5-dimethylaniline), vanillin (4-hydroxy3-methoxybenzaldehyde), guaiacol (2-methoxyphenol), and ethanol on the laccase activity of $A$. blazei strains was examined. For this, $5 \mathrm{mM}$ of each inducer was added to the cultivation medium after 3 days of cultivation to obtain a final concentration of $0,0.5,1.0$, or $1.5 \mathrm{mM}$. Laccase activity was measured after every 3 days.

All the experiments were conducted using 4 replicates. Results were analyzed by variance analyses, and differences among averages were determined using Scott-Knott test $(P \leq 0.05)$.

\section{Laccase assay}

Laccase (EC 1.10.3.2) activity was determined by monitoring the oxidation of 2,2'-azinobis(3-ethylbenzothiazoline-6-sulfonic acid) (ABTS; Sigma; St. Louis, MO, USA). Laccase activity was determined in a reaction mixture containing $200 \mu \mathrm{L}$ cultivation medium, $700 \mu \mathrm{L}$ water, 450 $\mu \mathrm{L} 0.1 \mathrm{M}$ sodium acetate buffer ( $\mathrm{pH} 5.0$ ), and $150 \mu \mathrm{L} 1 \mathrm{mM} \mathrm{ABTS}$ and by incubating the reaction mixture at $30^{\circ} \mathrm{C}$ for $10 \mathrm{~min}$. The reaction was interrupted by adding $100 \mu \mathrm{L} 5 \%(\mathrm{w} / \mathrm{v})$ trichloroacetic acid. The volume of the reaction mixture was adjusted to $5 \mathrm{~mL}$ using water, and absorbance of the mixture was measured at $420 \mathrm{~nm}$. Oxidation of ABTS increased the absorbance of the mixture at $420 \mathrm{~nm}(\varepsilon=36,000 \mathrm{M} / \mathrm{cm})$. A mixture containing $200 \mu \mathrm{L}$ cultivation medium, $850 \mu \mathrm{L}$ water, and 450 $\mu \mathrm{L}$ sodium acetate buffer and a mixture containing $900 \mu \mathrm{L}$ water, $450 \mu \mathrm{L}$ sodium acetate buffer, and $150 \mu \mathrm{L}$ ABTS were used as analytical controls. Laccase activity was expressed in international units $(U)$ and was defined as the amount of enzyme required to oxidize $1 \mu \mathrm{mol}$ of substrate per minute.

\section{Molecular confirmation of strain identity}

Mycelia of all $A$. blazei strains were ground in liquid nitrogen, and genomic DNA was extracted using $\mathrm{CTAB}$ buffer $[2 \%(\mathrm{w} / \mathrm{v})$ cetyltrimethylammonium bromide, $1.4 \mathrm{M} \mathrm{NaCl}$, $100 \mathrm{mM}$ Tris- $\mathrm{HCl}$ (pH 8.0), 20 mM EDTA, 0.2\% (v/v) $\beta$-mercaptoethanol, and 0.01\% (w/v) proteinase K] according to a procedure described by Doyle and Doyle (1987). Primers ITS-1 (5'-TCCGTAGGTGAACCTGCGG-3') and ITS-4 (5'-TCCTCCGCTTATTGATATGC-3'; White et al., 1990) were used to amplify internal transcribed spacers (ITSs) from ribosomal DNA (rDNA). PCR was performed in $25 \mu \mathrm{L} 1 \mathrm{X}$ PCR amplification buffer containing $1.5 \mathrm{mM} \mathrm{MgCl}_{2}, 0.2 \mu \mathrm{M}$ of each primer, $100 \mu \mathrm{M}$ of each deoxynucleoside triphosphate, $25 \mathrm{ng}$ DNA, and $1.5 \mathrm{U}$ Taq DNA polymerase (Life Technologies, Carlsbad, CA, USA) by using Mastercycler Gradient Thermocycler (Eppendorf, Hamburg, Germany). PCR conditions were as follows: initial denaturation at $94^{\circ} \mathrm{C}$ for $4 \mathrm{~min} ; 35$ cycles of denaturation at $94^{\circ} \mathrm{C}$ for $30 \mathrm{~s}$, annealing at $56^{\circ} \mathrm{C}$ for $30 \mathrm{~s}$, and extension at $72^{\circ} \mathrm{C}$ for 30 
$\mathrm{s}$; and final extension at $72^{\circ} \mathrm{C}$ for $7 \mathrm{~min}$. Control reactions lacking template DNA were conducted in parallel. The PCR products were electrophoresed on $1 \%(\mathrm{w} / \mathrm{v})$ agarose gel prepared using TAE buffer (40 mM Tris-acetate and $1 \mathrm{mM}$ EDTA) and were stained using ethidium bromide $(0.5 \mathrm{mg} / \mathrm{mL})$. The PCR products were purified using Pure Link PCR Purification Kit (Life Technologies, Carlsbad, CA, USA) and were sequenced using ABI Prism 3100 Genetic Analyzer (Applied Biosystems, Carlsbad, CA, USA). ITS sequences were compared with other sequences present in the GenBank database (http://www.ncbi.nlm.nih.gov/genbank/) by using BLAST (http://blast.ncbi.nlm.nih.gov/).

\section{RESULTS AND DISCUSSION}

Amplification of ITS rDNA produced a unique 700-bp fragment for all the strains examined. In addition, direct sequencing and analysis of this fragment showed high sequence similarity, thus confirming that the 4 strains (U2-1, U2-2, U2-3, and U2-4) belonged to A. blazei. The sequences of the 700-bp fragment amplified from the genomic DNA of the $4 \mathrm{~A}$. blazei strains were deposited in GenBank under accession Nos. KF281110, KF281111, KF281112, and KF281113, respectively.

\section{Effect of nitrogen and copper concentrations on laccase and biomass production}

Table 1 shows the laccase activity of and biomass production by $A$. blazei U2-4 in the presence of different nitrogen (urea) and copper $\left(\mathrm{CuSO}_{4}\right)$ concentrations. In the absence of copper, the highest $(P \leq 0.05)$ laccase activity $(43.8 \mathrm{U} / \mathrm{mL})$ was obtained in the presence of $2.8 \mathrm{~g} / \mathrm{L}$ nitrogen; this value was $760 \%$ higher than that obtained with $0.28 \mathrm{~g} / \mathrm{L}$ nitrogen. Under these conditions, the highest laccase production by $A$. blazei U2-4 was 8.7-fold higher than that reported by Ullrich et al. (2005) for $A$. blazei strain cultivated in tomato juice $(5 \mathrm{U} / \mathrm{mL})$ and 4.5 -fold higher than that reported by Valle et al. (2014a) for the same strain cultivated in sugarcane molasses $(9.7 \mathrm{U} / \mathrm{mL})$.

\begin{tabular}{|c|c|c|c|c|}
\hline \multirow{2}{*}{$\mathrm{CuSO}_{4}(\mu \mathrm{M})$} & \multicolumn{2}{|c|}{$0.28 \mathrm{~g} / \mathrm{L}$ nitrogen } & \multicolumn{2}{|c|}{$2.8 \mathrm{~g} / \mathrm{L}$ nitrogen } \\
\hline & Laccase $(\mathrm{U} / \mathrm{mL})$ & Biomass (mg/mL) & Laccase $(\mathrm{U} / \mathrm{mL})$ & Biomass $(\mathrm{mg} / \mathrm{mL})$ \\
\hline 0 & $5.1 \pm 1.9^{c}$ & $1.3 \pm 0.1^{a}$ & $43.8 \pm 0.4^{\mathrm{a}}$ & $1.1 \pm 0.1^{\mathrm{a}}$ \\
\hline 50 & $44.2 \pm 0.7^{\mathrm{a}}$ & $1.1 \pm 0.1^{\mathrm{b}}$ & $44.2 \pm 0.4^{\mathrm{a}}$ & $0.9 \pm 0.1^{b}$ \\
\hline 100 & $45.2 \pm 0.2^{\mathrm{a}}$ & $0.5 \pm 0.1^{c}$ & $44.9 \pm 0.4^{a}$ & $0.8 \pm 0.1^{b}$ \\
\hline 150 & $45.7 \pm 0.4^{\mathrm{a}}$ & $0.5 \pm 0.1^{c}$ & $44.4 \pm 1.3^{\mathrm{a}}$ & $0.7 \pm 0.2^{c}$ \\
\hline 200 & $45.5 \pm 0.4^{\mathrm{a}}$ & $0.5 \pm 0.1^{c}$ & $45.0 \pm 1.8^{\mathrm{a}}$ & $0.8 \pm 0.1^{b}$ \\
\hline 250 & $44.7 \pm 1.2^{\mathrm{a}}$ & $0.5 \pm 0.1^{c}$ & $45.7 \pm 0.6^{a}$ & $0.4 \pm 0.1^{d}$ \\
\hline 300 & $43.3 \pm 1.4^{b}$ & $0.4 \pm 0.1^{c}$ & $45.4 \pm 0.3^{a}$ & $0.5 \pm 0.2^{\mathrm{d}}$ \\
\hline
\end{tabular}

Averages indicated by the same letter do not differ statistically according to the Scott-Knott test $(P \leq 0.05)$.

The influence of nitrogen on laccase production has been controversial, since increased enzyme activity has been observed in both situations, under limiting and non-limiting nitrogen, in basidiomycete fungi (Giardina et al., 2010). Nitrogen affects laccase production at the transcriptional level. However, different nitrogen concentrations exert different effects on laccase production by different fungal species. Higher nitrogen concentration increases laccase production by Pleurotus ostreatus and Lentinula edodes but decreases laccase production by Phanerochaete chrysosporium, Phlebia brevispora, Coriolus versicolor, and Pholiota mutabilis (Leatham and Kirk, 
1983). Laccase production by Lentinus crinitus increases in the presence of $2.8 \mathrm{~g} / \mathrm{L}$ nitrogen (Valle et al., 2014b) while that by $P$. ostreatus increases in the presence of $0.23 \mathrm{~g} / \mathrm{L}$ nitrogen (Hou et al., 2004). The results of the present study and those of other studies (Ullrich et al., 2005; D'Agostini et al., 2011; Valle et al., 2014a) suggest that nitrogen concentrations in the range of 1.5-3.0 g/L induce maximum laccase production by $A$. blazei. Further, use of a protein nitrogen source such as urea promotes laccase production while use of inorganic nitrogen decreases laccase production (Piscitelli et al., 2011).

All concentrations of copper examined in this study increased $(P \leq 0.05)$ the laccase activity of $A$. blazei U2-4 in the presence of $0.28 \mathrm{~g} / \mathrm{L}$ nitrogen (Table 1 ). Laccase activity in the cultivation medium containing $150 \mu \mathrm{M}$ copper was 9 -fold higher $(45.7 \mathrm{U} / \mathrm{mL})$ than that in the control medium lacking copper $(5.1 \mathrm{U} / \mathrm{mL})$. However, addition of $\mathrm{CuSO}_{4}$ to the cultivation medium containing 2.8 $\mathrm{g} / \mathrm{L}$ nitrogen did not significantly increase laccase production. This has also been reported for laccase production by other fungal species. Laccase production by $P$. ostreatus was high in a nitrogen-limited medium containing $1 \mathrm{mM}$ copper (400 U/mL; Baldrian and Gabriel, 2002). Copper is one of the most efficient inducers of laccase activity because it is required for the synthesis of copper-containing polyphenol oxidases. Furthermore, copper regulates the expression of laccaseencoding genes in various fungal species through metal-responsive elements present in the promoter regions of these genes (Nitheranont et al., 2011).

The finding that addition of copper to the cultivation medium increased the laccase activity of $A$. blazei strains suggested that copper affected mechanisms regulating the transcription of laccase-encoding genes in these strains.

Biomass production by $A$. blazei U2-4 was inversely proportional to copper concentration (Table 1). Biomass production decreased $(P \leq 0.05)$ in the presence of copper and reached a minimum concentration of $0.4 \mathrm{mg} / \mathrm{mL}$ in the presence of $300 \mu \mathrm{M} \mathrm{CuSO}_{4}$. Free copper ions exert oxidative stress that reduces fungal growth; this may be the reason for low biomass production in the presence of higher copper concentrations (Palmieri et al., 2000). However did not affect laccase production by $A$. blazei.

\section{Effect of different compounds on laccase and biomass production}

When other $A$. blazei strains (U2-3, U2-1, and U2-2) were cultured in the same medium (2.8 $\mathrm{g} / \mathrm{L}$ nitrogen and $150 \mu \mathrm{M}$ copper) that was used for cultivating $A$. blazei U2-4, maximum laccase activity $(\mathrm{P} \leq 0.05)$ was observed for $A$. blazei $\mathrm{U} 2-3(10.3 \mathrm{U} / \mathrm{mL})$ and $A$. blazei $\mathrm{U} 2-1(7.6 \mathrm{U} /$ $\mathrm{mL}$; Table 2) and minimum activity $(4.8 \mathrm{U} / \mathrm{mL})$ was observed for $A$. blazei U2-2. Laccase activity of these strains peaked on different days. Laccase activity of $A$. blazei U2-3 and $A$. blazei U2-4 was the highest $\left(0.07\right.$ and $0.05 \mathrm{U} \cdot \mathrm{mL}^{-1} \cdot \mathrm{h}^{-1}$, respectively; $\left.\mathrm{P} \leq 0.05\right)$ while that of $A$. blazei $\mathrm{U} 2-1$ and $A$. blazei U2-2 was the lowest (0.03 and $0.02 \mathrm{U} \cdot \mathrm{mL}^{-1} \cdot \mathrm{h}^{-1}$, respectively).

Addition of inducers to the culture medium increased laccase production (Table 2). To date, no data are available on the induction of laccase production of $A$. blazei strains. Different concentrations $(0,0.5,1.0$, and $1.5 \mathrm{mM})$ of inducers were examined to determine the concentration that resulted in the highest induction. Incubation of $A$. blazei strains with different inducers for 21 days exerted different effects on laccase activity.

Induction of laccase production by these compounds may be associated with the development of fungal responses to toxic aromatic compounds commonly produced during lignin degradation. Many compounds potentially induce laccase production. However, the effects of these 
compounds may vary depending on the fungal strain and type of compound and concentration used (Elisashvili et al., 2010; Piscitelli et al., 2011).

\begin{tabular}{|c|c|c|c|c|c|c|c|c|}
\hline Strain & $\mathrm{mM}$ & Control & Ethanol & Guaiacol & Pyrogallol & Vanillin & Veratryl alcohol & Xylidine \\
\hline \multirow[t]{4}{*}{ U2-1 } & 0.0 & $7.6 \pm 2.4^{a}$ & - & - & - & - & - & - \\
\hline & 0.5 & & $5.8 \pm 0.9^{\mathrm{a}}$ & NT & $3.5 \pm 1.2^{b}$ & $7.5 \pm 3.0^{\mathrm{a}}$ & $4.6 \pm 1.4^{\mathrm{b}}$ & $2.9 \pm 0.9^{b}$ \\
\hline & 1.0 & & $8.0 \pm 1.9^{\mathrm{a}}$ & NT & $3.1 \pm 0.3^{b}$ & $9.0 \pm 1.2^{\mathrm{a}}$ & $6.6 \pm 1.7^{\mathrm{a}}$ & $2.3 \pm 0.5^{b}$ \\
\hline & 1.5 & & $7.8 \pm 2.1^{a}$ & NT & $3.3 \pm 0.3^{b}$ & $6.2 \pm 0.5^{a}$ & $4.0 \pm 0.9^{b}$ & $2.5 \pm 0.7^{b}$ \\
\hline \multirow[t]{4}{*}{ U2-2 } & 0.0 & $4.8 \pm 1.4^{\circ}$ & - & - & - & - & - & - \\
\hline & 0.5 & & $6.0 \pm 0.8^{c}$ & $7.7 \pm 2.7^{b}$ & $0.5 \pm 0.0^{d}$ & $7.2 \pm 2.3^{\circ}$ & $5.6 \pm 0.6^{c}$ & $2.8 \pm 0.7^{\mathrm{d}}$ \\
\hline & 1.0 & & $10.5 \pm 4.4^{\mathrm{a}}$ & $5.4 \pm 1.0^{c}$ & $0.1 \pm 0.0^{d}$ & $6.5 \pm 1.0^{c}$ & $4.9 \pm 1.6^{\mathrm{c}}$ & $1.7 \pm 0.5^{\mathrm{d}}$ \\
\hline & 1.5 & & $8.2 \pm 1.4^{b}$ & $5.7 \pm 0.9^{c}$ & $0.1 \pm 0.0^{d}$ & $6.3 \pm 2.0^{c}$ & $6.7 \pm 2.1^{\circ}$ & $0.5 \pm 0.1^{\mathrm{d}}$ \\
\hline \multirow[t]{4}{*}{ U2-3 } & 0.0 & $10.3 \pm 1.0^{b}$ & - & - & - & - & - & - \\
\hline & 0.5 & & $11.3 \pm 0.2^{b}$ & $13.3 \pm 1.1^{\mathrm{a}}$ & $7.2 \pm 0.9^{d}$ & $15.0 \pm 1.4^{\mathrm{a}}$ & $8.2 \pm 0.0^{c}$ & $5.6 \pm 0.5^{\mathrm{d}}$ \\
\hline & 1.0 & & $10.6 \pm 0.2^{b}$ & $12.6 \pm 0.8^{\mathrm{a}}$ & $7.9 \pm 0.1^{\circ}$ & $13.7 \pm 1.5^{\mathrm{a}}$ & $8.9 \pm 0.9^{c}$ & $6.7 \pm 2.1^{\mathrm{d}}$ \\
\hline & 1.5 & & $10.5 \pm 1.9^{b}$ & $10.4 \pm 0.3^{b}$ & $6.8 \pm 1.3^{d}$ & $9.7 \pm 0.8^{\mathrm{b}}$ & $9.2 \pm 0.6^{c}$ & $5.7 \pm 0.1^{\mathrm{d}}$ \\
\hline \multirow[t]{4}{*}{ U2-4 } & 0.0 & $25.4 \pm 2.5^{\mathrm{b}}$ & - & - & - & - & - & - \\
\hline & 0.5 & & $28.7 \pm 0.8^{a}$ & $26.6 \pm 0.6^{\mathrm{a}}$ & $24.5 \pm 3.2^{b}$ & $27.0 \pm 0.6^{\mathrm{a}}$ & $27.1 \pm 0.5^{\mathrm{a}}$ & $26.6 \pm 1.0^{\mathrm{a}}$ \\
\hline & 1.0 & & $28.0 \pm 0.3^{\mathrm{a}}$ & $27.0 \pm 0.8^{\mathrm{a}}$ & $27.2 \pm 0.2^{\mathrm{a}}$ & $27.3 \pm 0.4^{\mathrm{a}}$ & $27.4 \pm 0.6^{\mathrm{a}}$ & $24.1 \pm 1.0^{b}$ \\
\hline & 1.5 & & $28.4 \pm 0.6^{\mathrm{a}}$ & $28.3 \pm 0.4^{\mathrm{a}}$ & $21.7 \pm 3.1^{\circ}$ & $27.4 \pm 0.2^{\mathrm{a}}$ & $27.7 \pm 3.6^{\mathrm{a}}$ & $16.2 \pm 1.4^{\mathrm{d}}$ \\
\hline
\end{tabular}

Control, without inducer; NT, not tested. Averages indicated by the same letter do not differ statistically according to the Scott-Knott test $(P \leq 0.05)$.

The results of the present study are consistent with the above findings because different strains examined in this study responded differently to the same inducer. Different compounds differentially induced laccase production by $A$. blazei strains; moreover, different concentrations of these compounds exerted different effects on the laccase activity of $A$. blazei strains examined.

The maximum laccase activity of $A$. blazei $\mathrm{U} 2-1$ was not affected by the different inducers tested (Table 2). Ethanol and vanillin decreased the time required for achieving peak laccase activity from 12 days to 6 days, indicating a $67 \%$ increment in productivity. Maximum laccase activity of $A$. blazei $\mathrm{U} 2-2$ was achieved only in the presence of $0.5 \mathrm{mM}$ guaiacol and 1.0 and 1.5 $\mathrm{mM}$ ethanol (Table 2). Laccase activity of $A$. blazei $\mathrm{U} 2-3$ was higher $(\mathrm{P} \leq 0.05)$ in the presence of vanillin and guaiacol $(0.5$ and $1.0 \mathrm{mM}$ for both). However, the time required for achieving peak laccase activity with these inducers increased from 6 days to 15 days, indicating a $43 \%$ reduction in productivity. All the concentrations of xylidine and pyrogallol examined in this study decreased the laccase activity of $A$. blazei U2-1, A. blazei U2-2, and A. blazei U2-3.

All the compounds tested induced the laccase activity of $A$. blazei U2-4 (Table 2). Ethanol, guaiacol, vanillin, and veratryl alcohol increased laccase activity at all the concentrations tested. However, veratryl alcohol was the only inducer that decreased the time required for achieving peak laccase activity from 21 days to 6 days, indicating a 300\% increase in productivity. Only 1.0 $\mathrm{mM}$ pyrogallol induced the laccase activity of $A$. blazei U2-4. It should be noted that pyrogallol inhibited the laccase activity of $A$. blazei $\mathrm{U} 2-4$ initially after its addition to the cultivation medium. Although no laccase production was detected in the first 3 days after pyrogallol addition, the fungus retained its laccase-producing capacity. The laccase activity of $A$. blazei U2-4 increased again after approximately 15 days of pyrogallol addition and reached a maximum after 21 days. Xylidine increased laccase activity at a concentration of $0.5 \mathrm{mM}$.

Pyrogallol, a catechol derivative, decreased the maximum laccase activity of all the strains examined (Table 1). A. blazei U2-4 retained its laccase-producing capacity in the presence of 
pyrogallol, indicating that despite the initial inhibition, mycelia of $A$. blazeiU2-4 remained metabolically active. Pyrogallol also strongly decreased the laccase activity of Pycnoporus cinnabarinus and Coriolus hirsutus (Eggert et al., 1996) but increased the laccase activity of Cerrena unicolor by 2.5 fold (Elisashvili et al., 2010). Because pyrogallol increased fungal growth (Table 3), the delayed peak in the laccase activity of $A$. blazei $\cup 2-4$ may be because of an increase in biomass. This result may be because of the inhibition of constitutive forms of laccase and expression of new isoforms (Matsumoto-Akanuma et al., 2014). However, other strains examined in this study did not retain their laccase-producing capacity during fermentation and levels of laccases produced by these strains remained low.

Veratryl alcohol significantly increased the maximum laccase activity of $A$. blazei U2-4 (Table 2), with a large increment in productivity. An ideal inducer should increase enzyme production and activity and decrease fermentation time (Elisashvili et al., 2010). Veratryl alcohol is a potent inducer of laccase activity and has been used in various studies involving different fungi (Piscitelli et al., 2011). Xavier et al. (2007) showed that different concentrations of veratryl alcohol induced the laccase activity of Trametes versicolor. However, some studies indicated that veratryl alcohol did not induce laccase activity (Hou et al., 2004). Varied response to veratryl alcohol observed in the present study indicates a strong effect of fungal strains on laccase activity because cultivation conditions and veratryl alcohol concentration were the same for all the strains.

We observed that addition of xylidine significantly decreased the maximum laccase activity of all the strains (Table 2), except that of $A$. blazei $\cup 2-4$, which increased by $5 \%$ in the presence of $0.5 \mathrm{mM}$ xylidine. Xylidine induces laccase production in many fungi (Xiao et al., 2004). However, specific concentrations of xylidine may exert a toxic effect on some fungi and inhibit laccase production. Many studies have shown that only lower concentrations of xylidine induce laccase production (Hou et al., 2004; Xavier et al., 2007). The negative effect of xylidine on the laccase activity of $A$. blazei strains examined in the present study may be because of the concentrations of xylidine used (0.5-1.5 mM).

Vanillin significantly increased the maximum laccase activity of $A$. blazei U2-3 and $A$. blaze $i$ U2-4. The effect of vanillin on the induction of laccase activity has been reported previously (Piscitelli et al., 2011). Addition of vanillin to the cultivation medium of Trametes sp. AH28-2 significantly increased its laccase activity and induced the expression of a specific laccase isoenzyme (Xiao et al., 2004). The induction effect of vanillin seems to be influenced by other aspects of fermentation. Vanillin decreased the laccase activity of $C$. unicolor grown in a medium containing mannitol. However, vanillin treatment of $C$. unicolor grown in a synthetic medium containing a residue of ethanol production improved laccase activity (Elisashvili et al., 2010), indicating that cultivation conditions also influenced the induction of laccase activity by specific compounds.

Guaiacol and ethanol were excellent inducers of the laccase activity of $A$. blazei strains. Guaiacol and ethanol were the only compounds that increased the maximum laccase activity of A. blazei $\mathrm{U} 2-2$ by 60 and $120 \%$, respectively. Addition of $35 \mathrm{~g} / \mathrm{L}$ ethanol to solid-state fermentation with Pycnoporus cinnabarinus ss 3 increased the laccase activity of this fungus by 155 -fold relative to that of the control (Lomascolo et al., 2003).

Most inducers of laccase production are expensive and toxic. Applicability of new laccases to different industrial processes depends on the use of less toxic, cheaper, and easily available inducers (Hou et al., 2004). Ethanol is an optimal inducer of laccase production by A. blazei because it is cheaper, more easily available, and less toxic than other compounds commonly used for inducing laccase production. 
Comparison of the results of the present study with those of previous studies indicated that $A$. blazei strains analyzed in the present study were excellent laccase producers and showed diverse responses to the different inducers examined. Responses of these strains depend on their physiology and genetic and ecological characteristics (Elisashvili et al., 2010). In addition, different concentrations of inducers differentially induce laccase production. Different compounds induce different responses in basidiomycete fungi (Chen et al., 2003); therefore, no compound can be used as a universal inducer of enzyme synthesis by these fungi. Therefore, it is important to analyze different potential compounds and not discard effective laccase inducers during the initial screening steps.

Different $A$. blazei strains examined in the present study grew well in the presence of all the inducers evaluated (Table 3). Although pyrogallol and xylidine decreased laccase activity, they stimulated biomass production. Bolag and Leonowicz (1984) observed that xylidine did not exert any effect on biomass production by Fomes annosus, Pholiota mutabilis, P. ostreatus, and T. versicolor. Similarly, other authors (Elisashvili et al., 2010) did not observe any changes in biomass production by $C$. unicolor in the presence of pyrogallol, vanillin, or xylidine. Veratryl alcohol was the only compound that did not affect biomass production by any strain. Ethanol stimulated the growth of $A$. blazei U2-2 and A. blazei U2-4, which was in contrast to that observed by Lomascolo et al. (2003) who reported $70 \%$ reduction in the radial growth of Pycnoporus cinnabarinus in the presence of ethanol.

\begin{tabular}{|c|c|c|c|c|c|c|c|c|}
\hline Strain & $\mathrm{mM}$ & Control & Ethanol & Guaiacol & Pyrogallol & Vanillin & Veratryl alcohol & Xylidine \\
\hline \multirow{4}{*}{ U2-1 } & 0.0 & $0.26 \pm 0.01^{\mathrm{c}}$ & - & - & - & - & - & - \\
\hline & 0.5 & & $0.31 \pm 0.00^{\circ}$ & NT & $0.49 \pm 0.02^{\mathrm{a}}$ & $0.24 \pm 0.02^{c}$ & $0.21 \pm 0.03^{c}$ & $0.25 \pm 0.00^{c}$ \\
\hline & 1.0 & & $0.25 \pm 0.02^{\mathrm{c}}$ & NT & $0.34 \pm 0.01^{\mathrm{b}}$ & $0.38 \pm 0.03^{b}$ & $0.29 \pm 0.06^{c}$ & $0.23 \pm 0.05^{c}$ \\
\hline & 1.5 & & $0.23 \pm 0.01^{\mathrm{c}}$ & NT & $0.39 \pm 0.00^{b}$ & $0.44 \pm 0.00^{\mathrm{a}}$ & $0.20 \pm 0.01^{c}$ & $0.21 \pm 0.01^{c}$ \\
\hline \multirow[t]{4}{*}{ U2-2 } & 0.0 & $0.10 \pm 0.03^{b}$ & - & - & - & - & - & - \\
\hline & 0.5 & & $0.19 \pm 0.06^{a}$ & $0.16 \pm 0.04^{b}$ & $0.20 \pm 0.01^{a}$ & $0.10 \pm 0.03^{b}$ & $0.10 \pm 0.04^{b}$ & $0.17 \pm 0.00^{\mathrm{a}}$ \\
\hline & 1.0 & & $0.19 \pm 0.09^{a}$ & $0.11 \pm 0.05^{b}$ & $0.22 \pm 0.05^{a}$ & $0.14 \pm 0.01^{\mathrm{b}}$ & $0.10 \pm 0.01^{b}$ & $0.21 \pm 0.03^{a}$ \\
\hline & 1.5 & & $0.10 \pm 0.01^{\mathrm{b}}$ & $0.17 \pm 0.01^{\mathrm{a}}$ & $0.10 \pm 0.04^{b}$ & $0.25 \pm 0.01^{\mathrm{a}}$ & $0.10 \pm 0.01^{b}$ & $0.13 \pm 0.02^{b}$ \\
\hline \multirow[t]{4}{*}{ U2-3 } & 0.0 & $0.20 \pm 0.05^{b}$ & - & - & - & - & - & - \\
\hline & 0.5 & & $0.19 \pm 0.00^{\mathrm{b}}$ & $0.32 \pm 0.01^{\mathrm{a}}$ & $0.44 \pm 0.02^{\mathrm{a}}$ & $0.24 \pm 0.07^{b}$ & $0.24 \pm 0.05^{\mathrm{b}}$ & $0.33 \pm 0.01^{a}$ \\
\hline & 1.0 & & $0.18 \pm 0.02^{b}$ & $0.35 \pm 0.04^{a}$ & $0.09 \pm 0.00^{b}$ & $0.26 \pm 0.06^{b}$ & $0.19 \pm 0.08^{b}$ & $0.30 \pm 0.08^{a}$ \\
\hline & 1.5 & & $0.16 \pm 0.01^{\mathrm{b}}$ & $0.38 \pm 0.03^{a}$ & $0.24 \pm 0.05^{b}$ & $0.30 \pm 0.04^{\mathrm{a}}$ & $0.18 \pm 0.09^{b}$ & $0.37 \pm 0.02^{\mathrm{a}}$ \\
\hline \multirow[t]{4}{*}{ U2-4 } & 0.0 & $0.85 \pm 0.03^{c}$ & - & - & - & - & - & - \\
\hline & 0.5 & & $0.94 \pm 0.01^{\mathrm{b}}$ & $1.17 \pm 0.05^{\circ}$ & $1.20 \pm 0.04^{b}$ & $1.04 \pm 0.01^{\mathrm{b}}$ & $0.74 \pm 0.03^{c}$ & $0.77 \pm 0.08^{c}$ \\
\hline & 1.0 & & $1.00 \pm 0.06^{\mathrm{b}}$ & $0.84 \pm 0.04^{\circ}$ & $1.62 \pm 0.03^{a}$ & $1.01 \pm 0.08^{\mathrm{b}}$ & $0.82 \pm 0.08^{c}$ & $0.57 \pm 0.15^{c}$ \\
\hline & 1.5 & & $1.06 \pm 0.05^{\mathrm{b}}$ & $1.11 \pm 0.06^{b}$ & $1.80 \pm 0.11^{a}$ & $1.13 \pm 0.02^{b}$ & $0.75 \pm 0.08^{c}$ & $0.54 \pm 0.04^{c}$ \\
\hline
\end{tabular}

Control, without inducer; NT, not tested. Averages indicated by the same letter do not differ statistically according to the Scott-Knott test $(P \leq 0.05)$.

In conclusion, different culture conditions significantly affected laccase production by $A$. blazei strains. A. blazei U2-4 produced high laccase levels in a medium containing glucose (10 g/L), nitrogen supplied as urea $(2.8 \mathrm{~g} / \mathrm{L})$, and copper supplied as $\mathrm{CuSO}_{4}(150 \mu \mathrm{M})$. All the compounds examined in this study differentially induced laccase production. Moreover, we observed that the same compound functioned as an inducer or a repressor depending on the fungal strain used. Ethanol, guaiacol, veratryl alcohol, and vanillin induced laccase activity while pyrogallol and xylidine had no effect on laccase activity. 


\section{ACKNOWLEDGMENTS}

The authors would like to thank UNIPAR for partially funding this study. JS Valle received financial support from UNIPAR. LPS Vandenberghe would like to thank Coordenação de Aperfeiçoamento de Pessoal de Nível Superior and Conselho Nacional de Desenvolvimento Científico e Tecnológico.

\section{REFERENCES}

Baldrian P (2006). Fungal laccases: occurrence and properties. FEMS Microbiol. Rev. 30: 215-42.

Baldrian P and Gabriel J (2002). Copper and cadmium increase laccase activity in Pleurotus ostreatus. FEMS Microbiol. Lett. 206: 69-74.

Bertéli MB, Umeo SH, Bertéli A, Valle JS, et al. (2014). Mycelial antineoplastic activity of Agaricus blazei. World J. Microbiol. Biotechnol. 30: 2307-2313.

Bollag JM and Leonowicz A (1984). Comparative studies of extracellular fungal laccases. Appl. Environ. Microb. 48: 849-854.

Chen S, Ma D, Ge W and Buswell JA (2003). Induction of laccase activity in the edible straw mushroom, Volvariella volvacea. FEMS Microbiol. Lett. 218: 143-148.

Costa MCD, Regina M, Cilião Filho M, Linde GA, et al. (2015). Photoprotective and antimutagenic activity of Agaricus subrufescens basidiocarp extracts. Curr. Microbiol. Doi: 10.1007/s00284-015-0859-x.

D’Agostini EC, Mantovani TRD, Valle JS, Paccola-Meireles LD, et al. (2011). Low carbon/nitrogen ratio increases laccase production from basidiomycetes in solid substrate cultivation. Sci. Agric. 68: 295-300.

Doyle JJ and Doyle JL (1987). A rapid isolation procedure for small quantities of fresh leaf tissue. Phytochem. Bull. 19: 11-15.

Durrant AJ, Wood DA and Cain RB (1991). Lignocellulose biodegradation by Agaricus bisporus during solid substrate fermentation. J. Gen. Microbiol. 137: 751-755.

Eggert C, Temp U and Eriksson KE (1996). The ligninolytic system of the white rot fungus Pycnoporus cinnabarinus: purification and characterization of the laccase. Appl. Environ. Microb. 62: 1151-1158.

Eira AF, Didukh MY, Stamets P, Wasser SP, et al. (2002). Is a widely cultivated culinary-medicinal royal sun Agaricus (the himematsutake mushroom) indeed Agaricus blazei Murrill? Int. J. Med. Mushrooms 4: 267-90.

Elisashvili V and Kachlishvili E (2009). Physiological regulation of laccase and manganese peroxidase production by white-rot Basidiomycetes. J. Biotechnol. 144: 37-42.

Elisashvili V, Kachlishvili E, Khardziani T and Agathos SN (2010). Effect of aromatic compounds on the production of laccase and manganese peroxidase by white-rot basidiomycetes. J. Ind. Microbiol. Biot. 37: 1091-1096.

Galhaup C, Wagner H, Hinterstoisser B and Haltrich D (2002). Increased production of laccase by the wood-degrading basidiomycete Trametes pubescens. Enzyme Microb. Technol. 30: 529-536.

Giardina P, Faraco V, Pezzella C, Piscitelli A, et al. (2010). Laccases: a never-ending story. Cell Mol. Life Sci. 67: $369-385$.

Han MJ, Choi HT and Song HG (2005). Purification and characterization of laccase from the white rot fungus Trametes versicolor. J. Biotechnol. 43: 555-560.

Hou H, Zhou J, Wang J, Du C, et al. (2004). Enhancement of laccase production by Pleurotus ostreatus and its use for the decolorization of anthraquinone dye. Process Biochem. 39: 1415-1419.

Kerrigan RW (2005). Agaricus subrufescens, a cultivated edible and medicinal mushroom, and its synonyms. Mycologia 97: 12-24.

Leatham GF and Kirk TK (1983). Regulation of lignolytic activity by nutrient nitrogen in white-rot basidiomycetes. FEMS Microbiol. Lett. 16: 65-67.

Lomascolo A, Record E, Herpoël-Gimbert I, Delattre M, et al. (2003). Overproduction of laccase by a monokaryotic strain of Pycnoporus cinnabarinus using ethanol as inducer. J. Appl. Microbiol. 94: 618-624.

Matsumoto-Akanuma A, Akanuma S, Motoi M, Yamagishi A, et al. (2014). Cloning and characterization of laccase DNA from the royal sun medicinal mushroom, Agaricus brasiliensis (Higher Basidiomycetes). Int. J. Med. Mushrooms 16: 375-393.

Nitheranont T, Watanabe A and Asada Y (2011). Extracellular laccase produced by an edible basidiomycetous mushroom, Grifola frondosa: purification and characterization. Biosci. Biotechnol. Biochem. 75: 538-543.

Palmieri G, Giardina P, Bianco C, Fontanella B, et al. (2000). Copper induction of laccase isoenzymes in the ligninolytic fungus Pleurotus ostreatus. Appl. Environ. Microbiol. 66: 920-924.

Piscitelli A, Giardina P, Lettera V, Pezzella C, et al. (2011). Induction and transcriptional regulation of laccases in fungi. Curr. Genomics 12: 104-112. 
Piscitelli A, Pezzella P, Giardina P, Faraco V, et al. (2010). Heterologous laccase production and its role in industrial applications. Bioeng. Bugs 1: 252-262.

Ullrich R, Huong M, Dung NL and Hofrichter M (2005). Laccase from the medicinal mushroom Agaricus blazei: production, purification and characterization. Appl. Microbiol. Biotechnol. 67: 357-363.

Valle JS, Vandenberghe LPS, Santana TT, Linde GA, et al. (2014a). Optimization of Agaricus blazei laccase production by submerged cultivation with sugarcane molasses. Afr. J. Microbiol. Res. 8: 939-946.

Valle JS, Vandenberghe LPS, Santana TT, Almeida PH, et al. (2014b). Optimum conditions for inducing laccase production in Lentinus crinitus. Genet. Mol. Res. 13: 8544-8551.

White TJ, Bruns T, Lee S and Taylor JW (1990). Amplification and direct sequencing of fungal ribosomal RNA genes for phylogenetics. In: PCR protocols: a guide to methods and applications (Innis MA, Gelfand DH, Sninsky JJ and White TJ, eds.). Academic Press, New York, 315-22.

Xavier AMRB, Tavares APM, Ferreira R and Amado F (2007). Trametes versicolor growth and laccase induction with byproducts of pulp and paper industry. Electron. J. Biotechnol. 10: 444-451.

Xiao YZ, Chen Q, Hang J, Shi YY, et al. (2004). Selective induction, purification and characterization of a laccase isozyme from the basidiomycete Trametes sp. AH28-2. Mycologia 96: 26-35. 